\title{
EGFR NM_005228.3:c.2283_2284ins12
}

National Cancer Institute

\section{Source}

National Cancer Institute. EGFR NM 005228.3:C.2283 2284ins12. NCI Thesaurus. Code C98603.

An insertion of 12 nucleotides, GAAGCCTTCCAG, between position 2283 and 2284 of the coding sequence of the EGFR gene. 